TNF may be key to the mechanism underlying TNF-mediated protection. Indeed, all TNF killing-resistant cell lines tested including $\mathrm{HeLa}$, Jurkat, U937, Sw480, H9, NIH 3T3, and Hut78 cells express IEX-1L after TNF stimulation (6, 8 ). In contrast, a decrease or delay in TNFinduced expression of IEX-1L is likely to increase cell susceptibility to TNF-induced apoptosis, as was found in p65KO3T3, JurkatI $\mathrm{B} \alpha \mathrm{M}$, and Jurkat cells bearing an antisense IEX-1L (4). Our unpublished data also showed that $I E X-1 \mathrm{~L}$ was potentially regulated by the RelA/c-rel complex (8), in agreement with previous observations that overexpression of the c-rel gene protected cells from TNF-induced cell death $(2,3)$ and that RelA gene knockout mice died at 15 days of gestation (14). However, unlike RelA-1- mice, mice lacking the c-rel gene are developmentally healthy (15), which suggests that $I E X-1 \mathrm{~L}$ may be only one of the NF-kB/Rel protein-regulated survival genes.

\section{References and Notes}

1. R. Beyaert and W. Fiers, FEBS Lett. 340, 9 (1994); D. Wallach, Trends Biochem. Sci. 22, 107 (1997).

2. H. Hsu, H. Shu, M. Pan, D. V. Goeddel, Cell 84, 299 (1996); Z. Liu, H. Hsu, D. V. Goeddel, M. Karin, ibid. 87, 565 (1996)

3. P. A. Baeuerle and D. Baltimore, ibid. 87, 13 (1996); M. Wu et al., EMBO J. 15, 4682 (1996); S. Nagata, Cell 88, 355 (1997).

4. A. A. Beg and D. Baltimore, Science 274, 782 (1996); C.-Y. Wang, M. W. Mayo, A. S. Baldwin Jr., ibid., p. 784; D. J. Van Antwerp, S. J. Martin, T. Kafri, D. R. Green, I. M. Verma, ibid., p. 787

5. P. Liang and A. B. Pardee, ibid. 257, 967 (1992).

6. A. D. Kondratyev, K. N. Chung, M. O. Jung, Cancer Res. 56, 1498 (1996); C. H. Charles, J. K. Yoon, J. S. Simske, L. F. Lau, Oncogene 8, 797 (1993); H. Schäfer, A. Trauzold, E. G. Siegel, U. R. Fölsch, W. E. Schmidt Cancer Res. 56, 2641 (1996).

7. GenBank accession number of IEX-1L CDNA AF039067.

8. M. Wu, R. Wu, Z. Ao, S. F. Schlossman, unpublished data. GenBank accession number of IEX-1 genomic DNA, AF071596.

9. $P C R$ products of the IEX-1 coding frame were in frame inserted into the $\mathrm{NH}_{2}$-terminus of GFP using the site Eco RI-Bam HI in a PEGFP-N1 plasmid (Clontech). The resulting PEGFP-IEX-1L and PEGFP-IEX-1S were digested and ligated to the site Hind III-Bam HI in a pCDNA plasmid (Invitrogen) containing HA epitope sequence at the $\mathrm{COOH}$-terminus of expressing protein. IEX-1L excised from pBluescript II/KS(-IEX-1L plasmid was subcloned into the Sal I-Not I site in a hygromycin-resistant gene-containing plasmid BCMGS/Hyg. PRc-Fas plasmid was a kind gift from S. M. Lehar (ImmunoCen Inc. Cambridge, MA).

10. The $A b$ was produced in rabbit by injecting affinitypurified glutathione S-transferase-IEX-1L fusion protein and was purified on a protein A column followed by an IEX-1L protein column. It reacted with both IEX-1L and IEX-1S proteins.

11. S. Takayama et al., Cell 80, 279 (1995); T. Torigoe et al., Cancer Res. 54, 4851 (1994); E. Yang and S. J. Korsmeyer, Blood 88, 386 (1996).

12. Jurkat cells or Jurkat I $\mathrm{k} \alpha \mathrm{M}$ cells were transfected by electroporation $(200 \mathrm{~V}, 960 \mu \mathrm{F})$ and $\mathrm{p} 65 \mathrm{KO} 3 \mathrm{~T} 3$ cells were transfected by the lipofectamine protocol (Gibco/BRL). Two days after transfection with the indicated plasmids, the cells were selected for neomycin $(1.5 \mathrm{mg} / \mathrm{ml})$ or hygromycin $(600 \mu \mathrm{g} / \mathrm{ml}$ for p65KO3T3 cells and $800 \mu \mathrm{g} / \mathrm{ml}$ for Jurkat $1 \kappa B \alpha M$ cells) resistance for 4 weeks and then their resistance to apoptosis induced by TNF or by mAb 7C11 to Fas [immunoglobulin $M$ (IgM), 1:10,000 diluted ascites) was tested. In each transfection of these bulk cul- tures, we used $5 \times 10^{6}$ cells and the efficiency of transfection was 8 to $20 \%$ for Jurkat and Jurkat IKB $\alpha M$ cells and 15 to $25 \%$ for p65KO3T3 cells, as tested by the PEGFP-IEX-1L plasmid. Thus, the results obtained from each of these bulk cultures theoretically represent about 0.4 to $1.2 \times 10^{6}$ individual clones.

13. K. Brown, S. Gerstberger, L. Carlson, G. Franzoso, U. Siebenlist, Science 267, 1485 (1995); J. A. S. Baldwin Ir., Annu. Rev. Immunol. 4, 649 (1996)

14. A. A. Beg, W. C. Sha, R. T. Bronson, S. Ghosh, D. Baltimore, Nature 376, 167 (1995).
15. F. Kontgen et al., Genes Dev. 9, 1965 (1995).

16. K. V. S. Prasad et al., Proc. Natl. Acad. Sci. U.S.A. 94 6346 (1997)

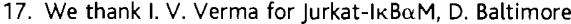
for p65KO3T3 cells, J. C. Reed for Bcl-2-transfected Jurkat cells, P. Anderson and H. Saito for their critical reading of the manuscript, and $\mathrm{H}$. Levine for flow cytometric analysis. Supported by National Institutes of Health grants p30Al28691 (to M.X.W) and Al12069 (to S.F.S).

17 March 1998; accepted 7 July 1998

\title{
Feedback Inhibition of Macrophage Tumor Necrosis Factor- $\alpha$ Production by Tristetraprolin
}

\author{
Ester Carballo,* Wi S. Lai,* Perry J. Blackshear $\dagger$
}

\begin{abstract}
Tumor necrosis factor- $\alpha$ (TNF- $\alpha)$ is a major mediator of both acute and chronic inflammatory responses in many diseases. Tristetraprolin (TTP), the prototype of a class of Cys-Cys-Cys-His (CCCH) zinc finger proteins, inhibited TNF- $\alpha$ production from macrophages by destabilizing its messenger RNA. This effect appeared to result from direct TTP binding to the AU-rich element of the TNF- $\alpha$ messenger RNA. TTP is a cytosolic protein in these cells, and its biosynthesis was induced by the same agents that stimulate TNF- $\alpha$ production, including TNF- $\alpha$ itself. These findings identify T TP as a component of a negative feedback loop that interferes with TNF- $\alpha$ production by destabilizing its messenger RNA. This pathway represents a potential target for anti-TNF- $\alpha$ therapies.
\end{abstract}

TNF- $\alpha$ is one of the principal mediators of the inflammatory response in mammals (1). In addition to its well-known role in acute septic shock, it has been implicated in the pathogenesis of chronic processes such as autoimmunity, graft-versus-host disease, rheumatoid arthritis, Crohn's disease, and the cachexia accompanying cancer and acquired immunodeficiency syndrome (2). Therapies such as neutralizing antibodies to TNF- $\alpha$ and chimeric soluble TNF- $\alpha$ receptors have demonstrated efficacy against some of these conditions in clinical trials (3).

We developed mice deficient in TTP, the prototype of a family of $\mathrm{CCCH}$ zinc finger proteins whose members have been identified in organisms ranging from humans to yeast (4-7). Although the TTP-deficient mice appear normal at birth, they soon develop a complex syndrome of inflammatory arthritis, dermatitis, cachexia, autoimmunity, and myeloid hyperplasia. Essentially all aspects of this syndrome can be prevented by repeated

Office of Clinical Research and Laboratory of Signal Transduction, National Institute of Environmental Health Sciences, Research Triangle Park, NC 27709, USA, and Departments of Medicine and Biochemistry, Duke University Medical Center, Durham, NC 27710 , USA.

*These authors contributed equally to this report. †To whom correspondence should be addressed. E mail: black009@niehs.nih.gov injections of antibodies to TNF- $\alpha(8)$. Macrophages derived from fetal liver of TTPdeficient mice, or from bone marrow precursors or resident peritoneal macrophages from adult mice, exhibited increased production of TNF- $\alpha$, as well as increased amounts of TNF- $\alpha$ mRNA, after stimulation with lipopolysaccharide (LPS) (9). For example, relative to control macrophages, bone marrowderived macrophages from the knockout mice secreted about five times as much TNF- $\alpha$ after incubation with LPS $(1 \mu \mathrm{g} / \mathrm{ml}$ for 4 hours), and amounts of TNF- $\alpha$ mRNA were about twice as large in the knockout cells as in the controls (9).

To investigate the mechanism of this effect, we evaluated the potential influence of TTP on TNF- $\alpha$ gene transcription. We transfected a human TTP genomic construct, in which the instability-inducing 3 '-untranslated region (UTR) of the TTP mRNA (10) was replaced by the 3'-UTR from the human growth hormone mRNA (11), with a TNF- $\alpha$ promoter-chloramphenicol acetyltransferase (CAT) reporter construct (Pro-CAT). This construct contained $2.3 \mathrm{~kb}$ of the mouse TNF- $\alpha$ promoter linked to the CAT coding sequence and a 3 '-UTR from a human growth hormone cDNA (12). Transfection of several cell types (chick embryo fibroblasts, NIH 3T3 mouse fibroblasts, and Rat-l fibroblasts) led to nonspecific "squelching" of several 


\section{REP OR T S}

cotransfected expression constructs, including Pro-CAT, SV2CAT (CAT driven by the SV40 promoter), and CAT driven by the Xenopus MARCKS gene promoter (13). In DNA dose-response studies in these cells, there was no evidence for preferential inhibition by the TTP constructs of Pro-CAT expression, relative to the expression of the other cotransfected constructs. In human 293 cells, which express little if any endogenous TTP (11), transfection of TTP constructs did not significantly inhibit the expression of cotransfected constructs (by paired $t$ test with the Bonferroni correction for multiple comparisons) (14). In experiments $(n=5)$ in which TTP was transfected with SV2CAT, TTP DNA was also without effect on CAT expression. Thus, the apparent effect of TTP to decrease amounts of TNF- $\alpha$ mRNA and protein in macrophages (9) appears not to result from inhibited TNF- $\alpha$ gene expression.

We evaluated the effect of TTP deficiency on the stability of TNF- $\alpha$ mRNA, which has a half-life of $12 \mathrm{~min}$ in human monocytes (15) and $39 \mathrm{~min}$ in the murine macrophage cell line Raw 264.7 (16). In bone marrowderived macrophages from wild-type $(n=6)$ and TTP-deficient mice $(n=6)$ that were stimulated with LPS ( $1 \mu \mathrm{g} / \mathrm{ml}$; Sigma) for 4 hours and then treated with actinomycin $\mathrm{D}(5$ $\mu \mathrm{g} / \mathrm{ml}$; Sigma), the half-life of TNF- $\alpha$ mRNA in the macrophages lacking TTP was significantly increased compared to that observed in the wild-type cells (Fig. 1). Northern (RNA) analysis showed no evidence of stable mRNA degradation products in either the control or TTP-deficient macrophages (Fig. 1A). Similar studies with TTP $(+/-)$ macrophages showed that TNF- $\alpha$ mRNA decayed at the same rate as in wild-type cells (17), indicating that $\sim 50 \%$ of normal cellular TTP concentration ( 8 ) is sufficient to confer normal lability to TNF- $\alpha$ mRNA under these experimental conditions.

These results suggest that TTP regulates amounts of TNF- $\alpha$ mRNA posttranscriptionally. This increased half-life of TNF- $\alpha$ mRNA in macrophages from the TTP-deficient mice is thus likely to be responsible for the increased secretion of TNF- $\alpha$ by macrophages derived from these mice ( 9 ) and for the syndrome of TNF- $\alpha$ excess that characterizes the TTP-deficient mice $(8,9)$.

TTP is localized in the nucleus of quiescent fibroblasts; the protein either remains in the nucleus ( 7 ) or rapidly ( $<5 \mathrm{~min}$ ) translocates to the cytosol after cells are stimulated with mitogens (18). To determine the subcellular localization of TTP in normal macrophages under these conditions, we incubated cells treated with LPS or TNF- $\alpha$ with $\left[{ }^{35} \mathrm{~S}\right]$ cysteine, separated them into nuclear and cytosolic fractions, and immunoprecipitated proteins with an antibody to TTP (18, 19). Both LPS and TNF- $\alpha$ caused an in- creased incorporation of ${ }^{35} \mathrm{~S}$ into cytosolic TTP 4 hours after stimulation (Fig. 2). Protein immunoblotting showed that increases in TTP protein were evident in the cytosol 30 min after treatment of cells with LPS, and that amount remained increased in the cytosol 2 to 4 hours after simulation (11). Nuclear TTP was not detectable in either the immunoprecipitation or the protein immunoblot experiments (Fig. 2).

Thus, TTP might participate in a negative feedback loop, in which the amount of TTP in the cytosol is increased by the same stimuli that cause increased expression of TNF- $\alpha$ in macrophages, leading to instability of TNF- $\alpha$ mRNA and inhibition of TNF- $\alpha$ secretion.
We therefore measured amounts of TTP mRNA in LPS-stimulated, bone marrow-derived macrophages from normal mice. In cells treated with LPS $(1 \mu \mathrm{g} / \mathrm{ml})$, TTP mRNA accumulated, peaking at $60 \mathrm{~min}$ (Fig. 3, A and B). The amount of TNF- $\alpha$ mRNA also increased, with a more prolonged time course (Fig. 3, C and D). Exposure of primary macrophages to recombinant murine TNF- $\alpha$ (10 $\mathrm{ng} / \mathrm{ml}$; R\&D Systems, Minneapolis) also resulted in increased amounts of TTP mRNA, which peaked after 30 to $60 \mathrm{~min}$ (Fig. 4, A and B). Amounts of TNF- $\alpha$ mRNA increased as well, peaking after 60 to $120 \mathrm{~min}$ (Fig. 4, $\mathrm{C}$ and $\mathrm{D})$.

TTP appears to regulate TNF- $\alpha$ synthesis
Fig. 1. Evaluation of TNF- $\alpha$ mRNA stability in macrophages from wild-type and T TP-deficient mice. Bone marrow-derived macrophages were prepared from six wildtype and six TTP-deficient mice (4 to 10 months old), as described (9). After washing twice with Dulbecco's modified Eagle's medium (DMEM) containing fetal calf serum $(10 \%)$, the cells were stimulated with LPS (1 $\mu \mathrm{g} / \mathrm{ml}$ ) for 4 hours, and then actinomycin $D(5$ $\mu \mathrm{g} / \mathrm{ml}$ ) was added for the indicated times. Cell harvesting total RNA extraction, and Northern analysis of TNF- $\alpha$ mRNA expression were done as described (9). The relative amounts of TNF- $\alpha$ mRNA were deter-

mined by Phosphorlmager analysis (Molecular Dynamics), and the results were normalized by reprobing the same blots with a CDNA coding for rat glyceraldehyde 3-phosphate dehydrogenase (GAPDH) (27). (A) Northern blot of TNF- $\alpha$ mRNA after addition of actinomycin D. WT, wild-type mice; KO, TTP-deficient mice. (B) Average values from the six experiments performed to assess TNF- $\alpha$ mRNA stability. Results are expressed as the mean relative amount of TNF- $\alpha$ mRNA \pm SEM at each time point, after correction for the amount of GAPDH mRNA ( ${ }^{*} P<0.05$ when comparing the means by Student's $t$ test; ${ }^{* *} p<0.01 ;{ }^{* * *} p<0.001$ ). The amount of mRNA at time 0 of actinomycin $D$ treatment was taken as $100 \%$ in each experiment. The inset shows a linear regression analysis of the 0 - to 60 -min values. WT $t_{1 / 2}=39 \mathrm{~min} ; \mathrm{KO} t_{1 / 2}=85 \mathrm{~min}$. Animal care was in accordance with institutional guidelines.

Fig. 2. Cellular localization of TTP in primary macrophages. Macrophages from wild-type mice were prepared as described (9) and grown to confluence in $100-\mathrm{mm}$ dishes. After stimulation with either LPS $(1 \mu \mathrm{g} / \mathrm{ml})$ or TNF- $\alpha$ (10 $\mathrm{ng} / \mathrm{ml}$ ), cells were divided into nuclear (N) and cytosolic (C) fractions (28). Positions of molecular size standards are indicated (in kilodaltons); Con, control. The arrow indicates the position of TTP. The sharp band of $M_{r} 44,000$ present in all the fractions is an artifact from the serum, as described (18).

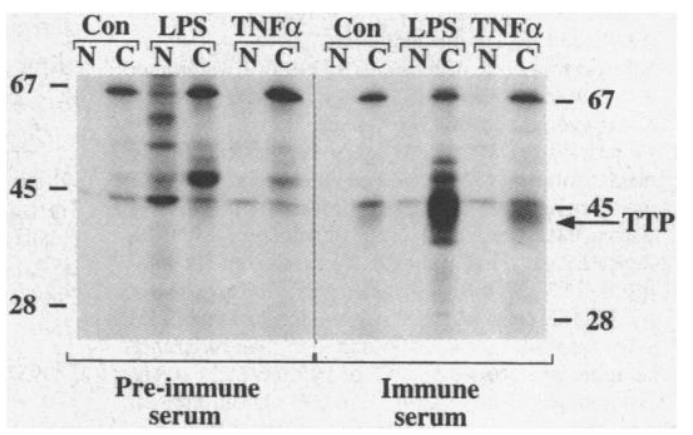




\section{REPOR T S}

by promoting the turnover of TNF- $\alpha$ mRNA. TNF- $\alpha$ promotes rather than inhibits its own synthesis and secretion (20) (Fig. 4), but our data indicate that negative feedback also exists through TNF- $\alpha$-induced or LPS-induced synthesis of TTP. When TTP is absent, as in the TTP-deficient mice, the self-stimulating property of TNF- $\alpha$ may lead to activation of inflammatory processes $(8,9)$.

TNF- $\alpha$ mRNA contains several AU-rich elements (AREs) as well as considerable predicted secondary structure, both of which can influence mRNA stability (2l). To investigate whether the TNF- $\alpha$ mRNA ARE was involved in the TTP effect, we cotransfected 293 cells with constructs expressing TTP (22) and constructs in which the AREs from TNF-

$\alpha$, granulocyte-macrophage colony-stimulating factor (GM-CSF), and interleukin 3 (IL$3)$ mRNAs were placed $3^{\prime}$ of the c-fos promoter and the $\beta$-globin protein coding sequence (23). Coexpression of human TTP ( 6 , $10)$, either with a genomic construct driven by the native human TTP promoter $(5 \mu \mathrm{g})$ or with a human TTP cDNA driven by the CMV promoter $(5 \mu \mathrm{g})$, markedly inhibited mRNA accumulation from all three constructs (Fig. 5A). Cotransfection with $0.01 \mu \mathrm{g}$ of the CMV-TTP construct or an unrelated CMVMLP construct (24) had little effect (Fig. 5A). TTP mRNA was highly expressed in the cells transfected with $5 \mu \mathrm{g}$ of the CMV-driven TTP, was expressed to an intermediate extent after $5 \mu \mathrm{g}$ of the TTP genomic construct, and

Fig. 3. TTP expression induced by LPS in macrophages. Primary macrophages were prepared from bone marrow of wild-type mice (9). Confluent 100-mm dishes were washed and exposed to LPS $(1 \mu \mathrm{g} / \mathrm{ml})$. RNA was obtained with an RNeasy kit (Qiagen) as directed by the manufacturer. (A) RNA from macrophages stimulated with LPS for the indicated times was analyzed by Northern blot with a mouse TTP CDNA (4). The blot shown is representative of three independent experiments. (B) Average values from three independent experiments, showing the amounts of TTP mRNA after LPS stimulation. Values were

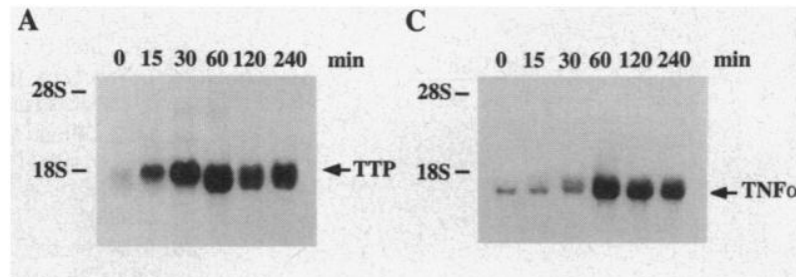

B

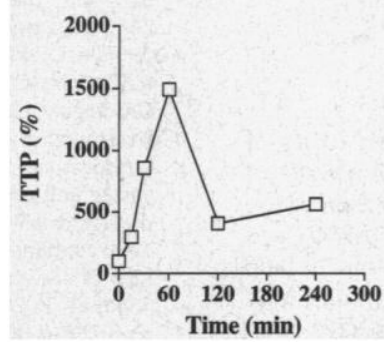

D

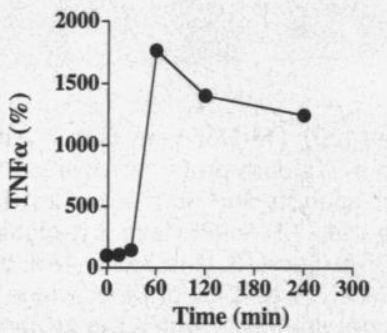

obtained with a Phosphorlmager and normalized for GAPDH mRNA expression, and final values were expressed as the percentage of the value at time 0 . (C) The same blot shown in (A) was stripped and reprobed with a mouse TNF- $\alpha$ CDNA. (D) Average values from three independent experiments, showing amounts of TNF- $\alpha$ mRNA after LPS stimulation.

Fig. 4. TNF- $\alpha$-induced expression of TTP in macrophages. Primary macrophages were prepared from bone marrow of wild-type mice as described (9). Confluent cells on 100-mm dishes were washed, exposed to TNF- $\alpha(10 \mathrm{ng} / \mathrm{ml})$, and processed for Northern blotting with the Qiagen RNeasy kit. (A) RNA from macrophages stimulated with TNF- $\alpha$ for the indicated times was analyzed by Northern blot with a mouse TTP cDNA (4). The blot shown is representative of three independent experiments. (B) Averages from three independent experiments showing amounts of TTP mRNA after TNF- $\alpha$ stimulation. (C) The blot shown in

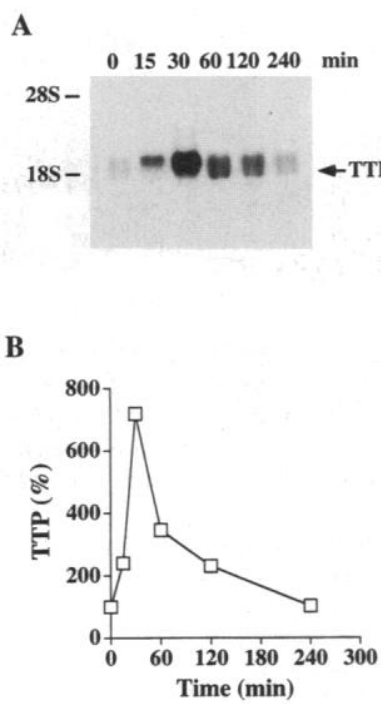

C

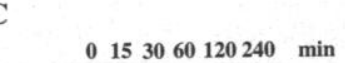

(A) was stripped and reprobed with a mouse TNF- $\alpha$ cDNA. (D) Average values from three independent experiments, showing amounts of TNF- $\alpha$ mRNA after TNF- $\alpha$ stimulation. was barely detectable after the $0.01-\mu \mathrm{g}$ concentration of CMV-TTP (Fig. 5B). Parallel experiments in which a c-fos promoter-CAT construct (25) was cotransfected with the TTP expression vectors revealed that the cfos promoter was not inhibited by the expression of the genomic TTP construct $(5 \mu \mathrm{g}), 5$ $\mu \mathrm{g}$ of the CMV-MLP construct, or $0.01 \mu \mathrm{g}$ of the CMV-TTP construct, whereas it was inhibited by about $30 \%$ by $5 \mu \mathrm{g}$ of the CMVTTP construct (11).

These results pointed to the ARE as the common element in these constructs responsible for TTP-induced mRNA lability. To test whether TTP affected binding of cellular proteins to this region of the TNF- $\alpha$ mRNA, we transfected 293 cells with a construct expressing epitope-tagged human TTP (22) and attempted to cross-link proteins in a cytosolic extract from these cells to a 153-bp probe from the mouse TNF- $\alpha 3^{\prime}$-UTR (26) that spanned the ARE. In untransfected cells, the radiolabeled mRNA probe was cross-linked to a major protein species of $\sim 85 \mathrm{kD}$ (Fig. 6 , lane 3). When extracts from TTP-expressing cells were used in a similar experiment, labeling of the $85-\mathrm{kD}$ protein decreased while a new binding protein of $\sim 40 \mathrm{kD}$ appeared (Fig. 6, lane 4). Immunoprecipitation with an antibody specific to the epitope tag revealed that the $40-\mathrm{kD}$ protein was TTP itself (Fig. 6, lane 8). Expression of the tagged protein in these cytosolic extracts was confirmed by protein immunoblotting (Fig. 6, lane 10); the protein that reacted with the epitope tag antibody also reacted with TTP antibodies (11). Essentially identical results were obtained when the probe was a 70-bp fragment consisting only of the TNF- $\alpha \operatorname{ARE}(11,26)$.

These data show that TTP binds directly to the ARE contained within the $3^{\prime}$-UTR of TNF- $\alpha$ mRNA - and probably of other labile, ARE-containing mRNAs - and suggest that this binding destabilizes these mRNAs. Because the TTP knockout mice display evidence of chronic TNF- $\alpha$ excess, and their macrophages hypersecrete TNF- $\alpha$, this interaction is likely to be of physiological importance. The data also suggest that the $\mathrm{CCCH}$ proteins as a class may be RNA-binding proteins; this should help in the elucidation of functions and binding partners for the other members of this protein family. Finally, this demonstration of direct binding of TTP to TNF- $\alpha$ mRNA, an interaction that presumably occurs in the cytosol, should permit the development of screening assays for compounds that potentiate, mimic, or increase the specificity of this reaction, and may ultimately lead to drugs capable of inhibiting TNF- $\alpha$ biosynthesis.

References and Notes

1. B. Beutler, J. Invest. Med. 43, 227 (1995)

2. C. O. Jacob, J. Autoimmun. 5 (suppl. A), 133 (1992); M. R. Shalaby, B. Fendly, K. C. Sheehan, R. D. Schrei- 
ber A J. Ammann, Transplantation 47, 1057 (1989) J. Cheng, K. Turksen, Q.-C. Yu, H. Schreiber, M. Ten Genes Dev. 6, 1444 (1992); J. Keffer et al., EMBO 10, 4025 (1991); J. M. Reimund et al., J. Clin. Immunol. 16, 144 (1996); M. Odeh, J. Intern. Med. 228 , 549 (1990).

3. H. M. Lorenz et al., J. Immunol. 156, 1646 (1996); E. Abraham et al., JAMA 277, 1531 (1997).

4. W. S. Lai, D. J. Stumpo, P. J. Blackshear, J. Biol. Chem 265, 16556 (1990)

5. B. C. Varnum, R. W. Lim, V. P. Sukhatme, H. R Herschman, Oncogene 4, 119 (1989); B. C Varnum, O. M. T. Chi, B. Fletcher, H. R. H Biol. 11, 1754 (1991); M. J. Thompson, W. S. Lai, G. A. Biol. 11, 1754 (1991); M. J. Thompson, W. S. Lai,
Taylor, P. J. Blackshear, Gene 174, 225 (1996).

6. G. A. Taylor et al., Nucleic Acids Res. 19, 3454 (1991)

7. R. N. DuBois, M. W. McLane, K. Ryder, L. F. Lau, D. A. Nathans, J. Biol. Chem. 265, 19185 (1990).

8. G. A. Taylor et al., Immunity 4, 445 (1996).

9. E. Carballo, G. S. Gilkeson, P. J. Blackshear, J. Clin. Invest. 100, 986 (1997)

10. W. S. Lai, M. J. Thompson, G. A. Taylor, Y. Liu, P. J. Blackshear, J. Biol. Chem. 270, 25266 (1995).

11. W. S. Lai, E. Carballo, P. J. Blackshear, unpublished data.
Fig. 5. Effect of TTP expression on accumulation of AREcontaining mRNAs. Constructs consisting of vector alone (5 $\mu g$, lanes 1), H6E.HGH3' (5 $\mu g$, lanes 2) CMV.T TP.tag $(0.01 \mu \mathrm{g}$, lanes 3; $5 \mu \mathrm{g}$, lanes 4), and a CMV MLP construct ( $5 \mu \mathrm{g}$, lanes 5$)$ were cotransfected into 293 cells with constructs consisting of the c-fos promoter, the $\beta$-globin coding region, and

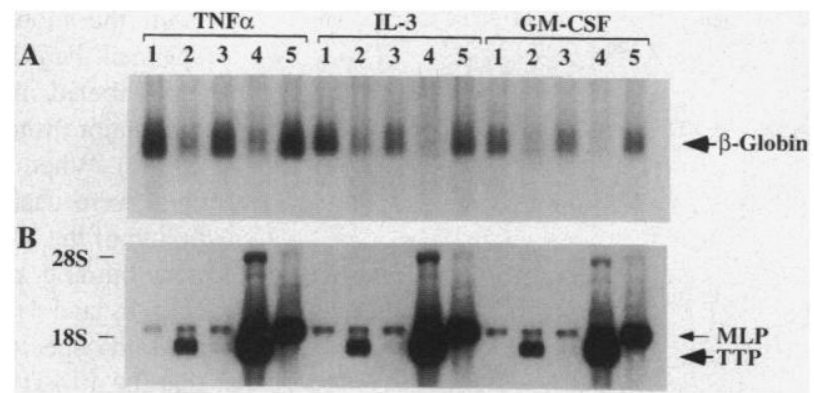

$3^{\prime}$-UTR into which were in-

serted AREs from TNF- $\alpha$, IL-3, or GM-CSF, as indicated (23). (A) Northern blot in which $10 \mu g$ of total cellular RNA from these cells was hybridized to a $\beta$-globin probe (arrowhead). Amounts of $\beta$-globin mRNA were quantitated by Phosphorlmager analysis and normalized to the expression of GAPDH in the same lane. For constructs containing the TNF- $\alpha$ ARE, lane $2 \beta$-globin mRNA was $42 \%$ of lane 1; lane 3, 90\%; lane 4, 26\%; and lane 5, 86\%. For IL-3, lane 2 was $43 \%$ of lane 1; lane 3, 66\%; lane 4, 29\%; and lane 5,87\%. For GM-CSF, lane 2 was $44 \%$ of lane 1 ; lane 3, 74\%; lane 4, 24\%; and lane 5, 103\%. (B) Northern blot of the same samples in which the gel lanes have been aligned with the lanes in (A), hybridized to a mouse TTP probe (arrowhead) or to a mouse MLP probe (arrow). The faint bands at the position of the arrow represent endogenous 293 cell MLP. The positions of the major species of ribosomal RNAs are shown.
12. B. Beutler and T. Brown, J. Clin. Invest. 87, 1336 (1991); J. Han, G. Huez, B. Beutler, J. Immunol. 146,

14. K. Godfrey, N. Engl. $J$. Med. $313,1450(1985)$

15. A. Jörres et al., Cytokine 9, 119 (1997).

6. J. Han, B. Beutler, G. Huez, Biochim. Biophys. Acta

18. G. A. Taylor, M. J. Thompson, W. S. Lai, P. J. BlackShear, Mol. Endocrinol. 10, 140 (1996).

19. Biol. Chem. 270, 13341 (1995).

G. Hensel, D. N. Mannel, K. Pfizenmaier, M. Krönke,
Lymphokine Res. 6, 119 (1987); D. R. Spriggs et al., Cancer Res. 50, 7101 (1990)

. G. Shaw and R. Kamen, Cell 46, 659 (1986); R. D. (1993); A. B. Sachs, ibid. 74, 413 (1993).

22. Plasmid H6E was first made by inserting a $3.7-\mathrm{kb}$ Eco RI-Xba I fragment from the human genomic TTP clone $(10)$ into the plasmid vector pBS+ (Stratfirst exon, the intron, the second exon, and 30 bp of 3'-flanking region. For H6E.HGH3', a 597-bp Nsi I-Xba I fragment in the $3^{\prime}$-UTR of the human TTP

Fig. 6. Cross-linking of cellular proteins to a TNF- $\alpha$ mRNA ARE probe. Cytosolic extracts were prepared from 293 cells 24 hours after they had been transfected with CMV. TTP.tag $(5 \mu \mathrm{g})$ or an equivalent amount of vector alone. Cells were lysed on ice for 20 min in $10 \mathrm{mM}$ Hepes (pH 7.6), $3 \mathrm{mM} \mathrm{MgCl}, 40 \mathrm{mM} \mathrm{KCl}, 5 \%(\mathrm{v} / \mathrm{v})$ glycerol, $0.5 \%(\mathrm{v} / \mathrm{v})$ $\mathrm{NP}-40,2 \mathrm{mM}$ dithiothreitol, $0.5 \mathrm{mM}$ PMSF, and leupeptin $(8 \mu \mathrm{g} / \mathrm{ml})$. The extracts were then centrifuged at $16,000 \mathrm{~g}$ at $4^{\circ} \mathrm{C}$ for $15 \mathrm{~min}$. Glycerol was added to the supernatant to $20 \%(\mathrm{v} / \mathrm{v})$, and the resulting cytosolic extract was stored at $-70^{\circ} \mathrm{C}$. Extracts $(20 \mu \mathrm{g}$ of protein) were incubated with $2 \times 10^{6} \mathrm{cpm}$ of RNA probe (26) in a 96-well plate at room temperature for $20 \mathrm{~min}$ in $0.02 \mathrm{ml}$ of the lysis buffer described above without the protease inhibitors. Heparin and yeast tRNA were added to final concentrations of 5 $\mathrm{mg} / \mathrm{ml}$ and $50 \mu \mathrm{g} / \mathrm{ml}$, respectively, for an additional $10 \mathrm{~min}$ of incubation. The 96 -well plate was then placed on ice and irradiated with $254-\mathrm{nm}$ ultraviolet light in a Stratalinker (Stratagene) for $30 \mathrm{~min}$ at a distance of $5 \mathrm{~cm}$ from the light source. RNA was then digested with 100 units of ribonuclease (RNase) T1 (Life Technologies, Gaithersburg, Maryland) for 20 min at room temperature, and further digested with RNase A (1 mg/ml; Pharmacia) at $37^{\circ} \mathrm{C}$ for $15 \mathrm{~min}$. The RNase-resistant RNA-protein complexes were then analyzed by SDS-PAGE followed by autoradiography. In the left panel, the arrowhead indicates undigested probe in lane 1, which has been digested in lane 2 . Lane 3 indicates cross-linking to a protein of $\sim 85 \mathrm{kD}$ in extracts of cells transfected with vector alone; lane 4 shows cross-linking of RNA to a protein of $\sim 40 \mathrm{kD}$ (arrow). In the center panel, identical RNase-resistant RNA-protein complexes from cells transfected with vector alone (lanes 5 and 6) or CMV.T TP.tag (lanes 7 and 8) were diluted to $0.5 \mathrm{ml}$ in a buffer consisting of $50 \mathrm{mM}$ tris- $\mathrm{HCl}(\mathrm{pH} 8.3), 150 \mathrm{mM} \mathrm{NaCl}, 5 \mathrm{mM}$ EDTA, and $1 \%$ (v/v) NP-40, then precleared with nonimmune rabbit serum $\left(1: 100\right.$ dilution, 1 hour at $\left.4^{\circ} \mathrm{C}\right)$ and protein $\mathrm{A}$-Sepharose $\left(1\right.$ hour at $\left.4^{\circ} \mathrm{C}\right)$, and then incubated overnight at $4^{\circ} \mathrm{C}$ in the presence of either preimmune serum (1:100; lanes 5 and 7) or a 1:100 dilution of HA.11, a polyclonal rabbit antibody to the HA epitope tag (BAbCO, Richmond, California) (lanes 6 and 8 ). Immune complexes were recovered by centrifugation after addition of protein A-Sepharose, washed three times with a buffer consisting of $50 \mathrm{mM}$ tris- $\mathrm{HCl}$ (pH 8.3), $150 \mathrm{mM} \mathrm{NaCl}, 1 \mathrm{mM}$ EDTA, and $0.5 \%(\mathrm{v} / \mathrm{v}) \mathrm{NP}-40$, resuspended in $0.1 \mathrm{ml}$ of SDS sample buffer, and subjected to SDS-PAGE and autoradiography. The arrow indicates the position of the immunoprecipitated ${ }^{32} \mathrm{P}$-labeled RNA-TTP complex. In the right panel, cytosolic extracts ( $7 \mu \mathrm{g}$ of protein) from cells transfected with $5 \mu \mathrm{g}$ of vector alone (lane 9 ) or $5 \mu \mathrm{g}$ of CMV.TTP.tag (lane 10) were separated on an SDS gel and subjected to immunoblotting with a rabbit antiserum to the HA epitope. The blot was visualized with chemiluminescence; the arrow indicates immunoreactive TTP. Positions of molecular size standards are indicated (in kilodaltons). gene that contained five rapid degradation signal sequences was replaced by the entire 110-bp human growth hormone ( $\mathrm{HCH}) 3^{\prime}$-UTR. The polymerase fragment were 5 '-GTGGCTTCTAGatgcatGGGTGGC ATC-3' (5' primer) and 5'-GAAGGACACCtctagaGACAAAATGATCC $-3^{\prime}$ ( $3^{\prime}$ primer), where capital letters represent the recognition sites for Nsi I (5' primer) and Xba I ( $3^{\prime}$ primer). For CMV.T TP.tag, the influenza hemagglutinin (HA) epitope tag [P. A. Kolodziej and R. A. Young, Methods Enzymol. 194, 508 (1991)] was attached to the last amino acid of the human TTP sis technique [W. S. Lai, M. ]. Thompson, P. J. Black shear, J. Biol. Chem. 273, 506 (1998)]. The fusion insert, containing the entire human TTP protein coding region and the $\mathrm{HA}$ epitope, was then cloned into the Hind III site of the vector CMV.BGH3'/BS+. This fragment from PRc/CMV2 (Invitrogen), which contains the hCMV promoter/enhancer and the bovine growth hormone polyadenylation signal, into the Eco RI and Hind III sites of PBS+ (Stratagene).

A.-B. Shyu, M. E. Greenberg, J. G. Belasco, Genes Dev. Cell. Biol. 17, 4611 (1997).
C. P. Blackshear, Genomics 17, 194 (1993). Gilman, P. J. Blackshear, J. Biol. Chem. 263, 1611
(1988). (1988).

RNA probes were prepared as follows: Plasmid P3'mTNF- $\alpha$, containing the mouse TNF- $\alpha 3^{\prime}$-UTR X02611), was created by reverse transcription (RT) PCR, with the use of total cellular RNA from Raw 264.7 cells treated for 4 hours with LPS $(1 \mu \mathrm{g} / \mathrm{ml})$ as templates for RT. The 5 ' primer was $5^{\prime}$-CT TTCCgaattCACTCGACCCTC- $3^{\prime}$, and the $3^{\prime}$ primer was $5^{\prime}-T A$ letters indicate the restriction sites for ECo RI and Xba $\mathrm{I}$, respectively). The resulting PCR fragment was digested and cloned into the Eco RI and Xba I sites of 1350 contained a 153-bp fragment that included the ARE of the mouse TNF- $\alpha 3^{\prime}$-UTR (bases 1197 to
1350 of $\mathrm{X02611);}$ this was made using plasmid $\mathrm{P}^{\prime} \mathrm{mTNF}-\alpha$ as the template. The $5^{\prime}$ primer was $5^{\prime}$-GATAagatctCAGGCCT TCC- $3^{\prime}$, and the $3^{\prime}$ primer resulting PCR product was digested with Bgl II and the vector PSK- (Stratagene). Plasmid pTNF- $\alpha 1197$ 
Xba I (sites indicated by lowercase letters in the primers) and cloned into the Bam $\mathrm{HI}$ and $\mathrm{Xba} I$ sites of the vector pSK-. Plasmid PTNF- $\alpha 1281-1350$ contained the seven AUUUA motifs of the TNF- $\alpha$ ARE (bases 1281 to 1350 of $\mathrm{X02611).} \mathrm{This} \mathrm{was} \mathrm{construct-}$ ed using similar methods. Correct sequences of these plasmids were confirmed by dideoxy sequencing (Amersham). For radiolabeling of the RNA transcripts with $[\alpha-32 \mathrm{P}]$ uridine triphosphate $(800 \mathrm{Ci} / \mathrm{mmol})$, plasmid TNF- $\alpha 1197-1350$ was linearized with Xba I and used as the template in the Riboprobe in vitro transcription system (Promega) protocol. The resulting product was precipitated with ammonium acetate and ethanol.

27. J. Y. Tso, X. H. Sun, T. H. Kao, K. S. Reece, R. Wu, Nucleic Acids Res. 13, 2485 (1985).

28. Confluent dishes were washed three times with cysteine-free medium supplemented with fetal calf serum $(10 \%)$. Cells were stimulated for 4 hours in the same medium with control conditions, LPS $(1 \mu \mathrm{g} / \mathrm{ml})$, or TNF- $\alpha(10 \mathrm{ng} / \mathrm{ml})$. For the last 3 hours of the incubation, $\left[{ }^{35} \mathrm{~S}\right]$ cysteine $(200 \mu \mathrm{Ci} / \mathrm{ml}$; NEN Life Sciences, Boston) was added to the cultures. Cells were washed twice with ice-cold PBS, scraped into $10 \mathrm{ml}$ of
PBS, and pelleted by centrifugation $(1000 \mathrm{~g}$ for $5 \mathrm{~min}$ at $4^{\circ} \mathrm{C}$ ). Cells were then resuspended in $600 \mu \mathrm{l}$ of lysis buffer [50 mM tris- $\mathrm{HCl}(\mathrm{pH} 7.5), 50 \mathrm{mM} \mathrm{NaCl}, 3$ $\mathrm{mM} \mathrm{MgCl}_{2}, 5 \%(\mathrm{v} / \mathrm{v})$ glycerol, $0.5 \%(\mathrm{v} / \mathrm{v})$ NP-40, $0.02 \%(\mathrm{w} / \mathrm{v})$ sodium azide, $5 \mathrm{mM}$ EDTA, $0.1 \mathrm{mM}$ phenylmethylsulfonyl fluoride (PMSF), soybean trypsin inhibitor $(20 \mu \mathrm{g} / \mathrm{ml})$, and leupeptin $(8 \mu \mathrm{g} / \mathrm{ml})]$, incubated on ice for $20 \mathrm{~min}$, and lysed by passage five times through a 28-gauge needle attached to a $1-\mathrm{ml}$ syringe with no dead space (Becton Dickinson). The nuclear pellet (after centrifugation at $1000 \mathrm{~g}$ for 5 min at $4^{\circ} \mathrm{C}$ ) was washed once in ice-cold wash buffer

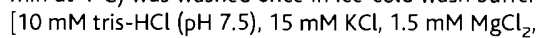
$0.5 \mathrm{mM}$ PMSF, and $5 \%$ glycerol], centrifuged at $1000 \mathrm{~g}$ for $5 \mathrm{~min}$ at $4^{\circ} \mathrm{C}$, and then resuspended and sonicated in the same volume of lysis buffer used initially to lyse the cells. The cytosolic fraction (supernatant) was clarified by centrifugation at $45,000 \mathrm{~g}$ for $30 \mathrm{~min}$ at $4^{\circ} \mathrm{C}$, using a tabletop ultracentrifuge (Beckman TL-100, rotor TLA.45). This method results in separation of cytosol and nuclear fractions, as assessed by protein immunoblotting with an antibody to SP1 as described (18). Cytosolic extracts matched by trichloroacetic acid-precipitable radioac- tivity and equivalent volumes of nuclear extracts were incubated with preimmune rabbit serum $(1: 100$ dilution, 1 hour at $4^{\circ} \mathrm{C}$ ) and protein A-Sepharose (1 hour at $4^{\circ} \mathrm{C}$ ), and then incubated overnight at $4^{\circ} \mathrm{C}$ in the presence of either preimmune serum $(1: 100)$ or a $1: 100$ dilution of a polyclonal rabbit antibody to mouse TTP $(18,19)$. Immune complexes were recovered by centrifugation after the addition of protein A-Sepharose, washed three times with wash buffer [50 mM tris- $\mathrm{HCl}$ (pH 8.3), $150 \mathrm{mM} \mathrm{NaCl}, 1$ mM EDTA, and $0.5 \% \mathrm{NP}-40]$, resuspended in $100 \mu \mathrm{l}$ of SDS sample buffer [P. J. Blackshear, Methods Enzymol. 104, 237 (1984)], and subjected to SDS-polyacrylamide gel electrophoresis (PACE) ( $9 \%$ gel). For autoradiography, gels were fixed and treated with Autofluor (National Diagnosties, Atlanta).

29. We thank A.-B. Shyu for the TNF- $\alpha, G M-C S F$, and IL-3 $\beta$-globin ARE constructs, B. Beutler for the Pro-CAT construct, M. Gilman and D. Stumpo for the fos-CAT construct, D. Germolec and A. Jetten for helpful comments on the manuscript, and E. Kennington for technical assistance.

23 February 1998; accepted 30 June 1998

\title{
Genetic Dissection of a Mammalian Replicator in the Human $\beta$-Globin Locus
}

\author{
Mirit I. Aladjem, Luo Wei Rodewald, John L. Kolman, \\ Geoffrey M. Wahl*
}

\begin{abstract}
The timing and localization of DNA replication initiation in mammalian cells are heritable traits, but it is not known whether initiation requires specific DNA sequences. A site-specific recombination strategy was used to show that DNA sequences previously identified as replication initiation sites could initiate replication when transferred to new chromosomal locations. An 8-kilobase DNA sequence encompassing the origin of DNA replication in the human $\beta$-globin locus initiated replication in the simian genome. Specific deletions within the globin origin did not initiate replication in these chromosomal sites. These data suggest that initiation of DNA replication in mammalian cells requires specific sequence information and extend the replicon hypothesis to higher eukaryotes.
\end{abstract}

The decision to initiate DNA replication is crucial to normal progression through the cell cycle ( $I$ ). The replicon model (2) proposed that cells regulate DNA replication by means of a bipartite control mechanism comprising a trans-acting "initiator" that interacts with a cis-acting DNA element called the replicator. The replicon model has been validated, with some modifications, in bacteria (3), prokaryotic and eukaryotic DNA viruses (4), and yeast (5). Identification of replicators in these systems was expedited by their ability to function in extrachromosomal plasmids (6). In mammalian cells, initiation can be localized to specific chromosomal regions by biochemical methods, but the chromosomal sites identified in this manner as initiation regions

Gene Expression Laboratory, The Salk Institute, San Diego, CA 92037, USA.

*To whom correspondence should be addressed at Gene Expression Laboratory, The Salk Institute, 10010 North Torrey Pines Road, San Diego, CA 92037, USA.
(IRs), origins or origins of bidirectional replication (OBRs), could not, by themselves, support replication of plasmids (7). This may be due to elimination of acentric extrachromosomal DNA (8), failure to license transfected DNA for initiation before it integrates (9), or greater complexity of mammalian replicators, exceeding the cloning capacity of the vectors used (7). Alternatively, replication initiation may be determined by a specific nuclear structure established within a defined cell cycle interval rather than by DNA sequence $(10)$.

We developed a genetic system to identify mammalian replicators on the basis of intrachromosomal initiation. Candidate replication origins that are included within lambda phage and cosmid clones can initiate DNA replication when transfected into mammalian cells and integrated into random sites (7), indicating that some specific DNA sequences or structures may act as replicators in ectopic chromosomal locations. If sequence-specific replicators exist, such sequences should initiate DNA replication when transferred to defined chromosomal sites that do not otherwise exhibit origin activity. Furthermore, if short, specific sequences direct initiation, then it should be possible to produce nonfunctional replicators by mutation or deletion. Because chromosome structure is an important component of replicator activity $(10-12)$, wild-type and variant replicators must be analyzed at the same chromosomal location.

Our approach (Fig. 1A) uses the site-specific recombinases FLP from yeast and Cre from bacteriophage $\mathrm{Pl}$ to target replicators to unique chromosomal locations containing the small target sequences recognized by these proteins (13). We analyzed the human $\beta$-globin $(h \beta G)$ IR using this approach because previous studies showed that cells with a naturally occurring deletion of the IR do not initiate replication within the $>70-\mathrm{kb}$ globin locus (14). Because initiation also requires the locus control region (LCR), located $\sim 50$ $\mathrm{kb}$ from the IR (11), we used the dual recombination system to create isogenic variants containing the IR with or without a $5^{\prime}$ miniLCR (Fig. IA).

We placed an 8-kb region from the $h \beta G$ locus that encompasses the IR in ectopic sites in the simian (Cercopithecus aethiops) genome (Fig. 1A). A polymerase chain reaction (PCR)-based nascent strand abundance assay (Fig. 1B) (15) revealed that short, newly replicated nascent strands were generated from the $\beta$-globin IR in both sites (Figs. 2A and 3) (16). Such short strands are produced from regions within which DNA replication initiates (11). By contrast, short nascent strands were not generated at detectable levels from the $\beta$-galactosidase ( $\beta$-Gal) gene sequences located $5 \mathrm{~kb} 3^{\prime}$ of the IR (Figs. $2 \mathrm{~A}$ and 3). Globin sequences were also present in preparations of small nascent strands ob- 